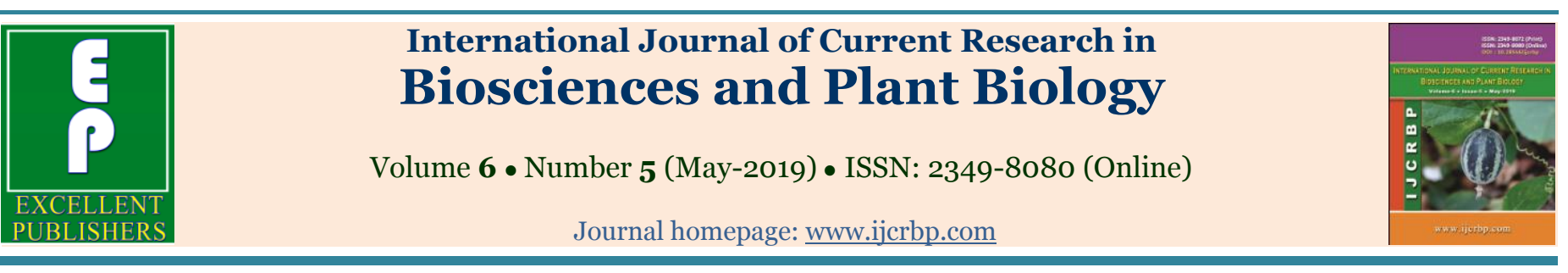

\title{
A study of potentially toxic elements in potato and cabbage grown in different regions of Uttar Pradesh
}

\author{
Archana Dwivedi ${ }^{*}$ and Uma Shankar²
}

\author{
${ }^{1}$ Directorate of Geology and Mining, Uttar Pradesh, India \\ ${ }^{2}$ Cytogene Research and Development C-302, Indra Nagar, Lucknow, India \\ ${ }^{*}$ Corresponding author; e-mail: archanashukladwi@gamil.com
}

\begin{tabular}{ll}
\hline Article Info & ABSTRACT \\
\hline $\begin{array}{l}\text { Date of Acceptance: } \\
\text { 18 April 2019 }\end{array}$ & $\begin{array}{l}\text { The study of heavy metals like lead, mercury, arsenic, zinc and copper has carried out in } \\
\text { two different vegetable (cabbage and potatoes) of Uttar Pradesh (UP). The results of } \\
\text { analysis revealed that all cabbage samples met Public Health Regulation Standards } \\
\text { regarding investigated metals. However, potatoes from nine investigated locations } \\
\text { Date of Publication: } \\
\text { o6 May 2019 }\end{array}$ \\
$\begin{array}{l}\text { exceeded the Maximum Permissible Concentrations (MPC) allocated for lead and met } \\
\text { the standards considering other investigated elements. In the view of obtained results, } \\
\text { pointing out lead as major problem regarding heavy metal pollution of investigated } \\
\text { vegetables. }\end{array}$ &
\end{tabular}

Heavy metal

Toxicity

\section{Introduction}

The environmental persistence of metals, additionally associated with their considerable use in modern society, resulted in accumulation of significant levels of these contaminants in the environment. They are being absorbed by plants to different extent depending on their source, soil and climatic factors, plant genotype and agrotechnical conditions, entering thereby the human food chain (McLaughlin et al. 1999). Some of them are essential for plant growth and /or different human metabolic processes in small amounts, resulting in adverse health effects at high levels of consumption while others show major toxic effects at the lowest rates of exposure.
The aim of our study was to determine contents of lead, total mercury, arsenic, cadmium, zinc and copper in samples of cabbage and potato, the most consumed vegetables in Uttar Pradesh, and to estimate dietary intake of investigated elements through potato and cabbage consumption. In the framework of our research we also assessed the impact of high temperature time operations on the quality of crops grown in that area several years after the western, regarding their content of investigated elements. $\mathrm{Pb}, \mathrm{Hg}$, As and $\mathrm{Cd}$ were chosen as target contaminants of the investigation because they are known to be the most important to consider in terms of food-chain contamination. The main sources of toxic metal emission to the environment are different anthropogenic 
activities such as industrial, agricultural and urban activities. Main sources of lead in the soil are atmospheric depositions from combustion of gasoline containing $\mathrm{Pb}$ additives (Andersson 1979). Mercury is usually added to soils in fertilizers and manure (Hutton 1983). Largest emissions of cadmium to the soil are by waste disposal, but also to the lesser degree through coal combustion, iron and steel production, phosphate fertilizers etc (Page 1972). Its concentrations in foodstuff vary widely, and considering food crops, the highest levels of that metal are found in leafy vegetables and rooty crops (Langdon 2003).

The greatest accumulation of arsenic occurs in the areas exposed to industrial effluents and especially in areas next to smelters and mine spoils (Palinkaš 1993). Earlier, the heavy metal and other related to biomonitoring studies has been carried out by various workers in the Uttar Pradesh but this study is first time carried out in the whole UP.

\section{Materials and methods}

\section{Sample collection and preparation}

Potato and white cabbage samples were collected in 20 different locations in UP; ten locations (samples $1-10$ ) are located in East UP. Other ten locations (samples $11-20$ ) are situated in the West part of the UP. From each location two heads of cabbage and $2 \times 1 \mathrm{~kg}$ of potato were collected. In cabbage samples all damaged outer leaves were removed and the rest of the sample was chopped and homogenized. Potatoes were washed several times with tap water, followed by distilled water, and after the excess water was wiped off using filter-paper, potatoes were peeled, chopped with disposable plastic knife to small pieces and mixed thoroughly. After high temperature, samples were first air dried for several days and then dried in an electric furnace at $105^{\circ} \mathrm{C}$ to constant weight. For further analysis samples were stored in polyethylene bottles at $4^{\circ} \mathrm{C}$. Moisture was determined in fresh samples by drying them to constant weight at $105^{\circ} \mathrm{C}$ in an electric furnace.

\section{Determination of toxic and potentially toxic elements}

In order to determine $\mathrm{Zn}, \mathrm{Cu}, \mathrm{Pb}, \mathrm{Cd}$, As and total $\mathrm{Hg}$ amounts in investigated vegetables, $1 \mathrm{~g}$ \pm 0.0001 of homogenized, dry samples were weight into the vessels and wet digested using $\mathrm{HNO}_{3}$ conc. and $30 \% \mathrm{H}_{2} \mathrm{O}_{2}$ in an microwave unit.( MLS-1200 Mega Microwave Digestion System). After digestion process, clear solutions were transferred to $50 \mathrm{ml}$ volumetric flasks and diluted with deionized water. Mercury and arsenic were determined by atomic absorption spectophotometry - AAS (Pye Unicam SP9 Atomic Absorption Spectrophotometer), using hydride technique at $193.7 \mathrm{~nm}$ (As) and $253.7 \mathrm{~nm}(\mathrm{Hg})$. Content of all other investigated elements were determined by inductively coupled plasma atomic emission spectroscopy - ICP-AES (Liberty 200 Inductively Coupled Plasma Atomic Emission Spectrometer). The analytical wavelengths of the elements of interest were as following: 228.802 $(\mathrm{Cd}), 220.353(\mathrm{~Pb}), 324.754(\mathrm{Cu})$ and 213.856 (Zn). All measurements were carried out in duplicates.

\section{Results and discussion}

Amounts of toxic and potentially toxic elements detected in investigated vegetables are shown in Table 1, and are characterized by a large variability within investigated groups. Arsenic was not detected in any of investigated samples, while measurable levels of mercury were only found in the part of investigated potato samples.

\section{Zinc and copper contents in investigated vegetables}

Zinc and copper levels were investigated in this context since too high intake of those, otherwise essential metals can show adverse health effects. The range of zinc contents were $1.7-3.4 \mathrm{mg} / \mathrm{kg}$ fresh weight (FW) (mean $2.5 \mathrm{mg} / \mathrm{kg} \mathrm{FW}$ ) in cabbage grown Western region and $0.97-4.27$ $\mathrm{mg} / \mathrm{kg}$ FW (mean $2.00 \mathrm{mg} / \mathrm{kg} \mathrm{FW}$ ) in samples from western affected locations. Although obtained results point to on an average higher $\mathrm{Zn}$ levels in samples from western region, performing statistical analysis showed that those differences were not statistically significant. Zinc levels found in potato samples were higher compared to those of cabbage and they ranged from 3.42 - 14.11 $\mathrm{mg} / \mathrm{kg}$ FW in Western region and $2.64-8.34$ $\mathrm{mg} / \mathrm{kg} \mathrm{FW}$ affected areas. The differences between the two groups of samples were statistically insignificant as well. 
Table 1. Content of toxic and potentially toxic elements in investigated samples.

\begin{tabular}{|c|c|c|c|c|c|c|c|c|c|c|c|c|}
\hline \multirow[b]{2}{*}{ Sampling site } & \multicolumn{4}{|c|}{ Cabbage (mg/kg FW) } & \multicolumn{8}{|c|}{ Potato (mg/kg FW) } \\
\hline & $\mathbf{C u}$ & $\mathbf{Z n}$ & $\mathbf{C d}$ & $\mathbf{P b}$ & Total Hg & As & $\mathbf{C u}$ & $\mathbf{Z n}$ & Cd & $\mathbf{P b}$ & Total Hg & As \\
\hline \multicolumn{13}{|c|}{ Eastern areas of Uttar Pradesh } \\
\hline Bahraich & 0.24 & 0.97 & 0.012 & 0.006 & $* /$ & / & 1.55 & 4.33 & 0.020 & 0.10 & 0.003 & / \\
\hline Gonda & 0.17 & 1.45 & 0.006 & 0.012 & / & / & 1.60 & 8.34 & 0.039 & 0.06 & 0.007 & / \\
\hline Allahabad & 0.23 & 1.80 & 0.008 & 0.023 & / & / & 1.59 & 5.10 & 0.059 & 0.14 & / & / \\
\hline Gorakhpur & 0.62 & 4.27 & 0.009 & 0.114 & / & / & 1.95 & 2.64 & 0.012 & 0.14 & / & / \\
\hline Deoria & 0.31 & 1.60 & 0.005 & 0.039 & / & / & 1.90 & 3.94 & 0.008 & 0.11 & / & / \\
\hline Azamgarh & 0.38 & 2.19 & 0.007 & 0.012 & / & / & 2.98 & 6.45 & 0.012 & 0.27 & 0.040 & / \\
\hline Varanasi & 0.38 & 2.35 & 0.007 & 0.020 & / & / & 1.87 & 4.57 & 0.010 & 0.08 & 0.025 & / \\
\hline Jaunpur & 0.33 & 2.33 & 0.006 & / & / & / & 1.85 & 3.96 & 0.027 & 0.14 & 0.030 & / \\
\hline Sultanpur & 0.25 & 1.59 & 0.007 & 0.018 & / & / & 1.71 & 4.05 & 0.022 & 0.06 & 0.010 & / \\
\hline Faizabad & 0.17 & 1.45 & 0.006 & 1 & I & 1 & 2.46 & 4.04 & 0.005 & 0.11 & 0.017 & I \\
\hline \multicolumn{13}{|c|}{ Western area of Uttar Pradesh } \\
\hline Saharanpur & 0.30 & 3.40 & 0.007 & 0.027 & / & / & 1.02 & 3.42 & 0.010 & 0.07 & 0.004 & / \\
\hline Moradabad & 0.40 & 2.91 & 0.017 & 0.021 & / & / & 1.67 & 5.85 & 0.063 & 0.06 & 0.017 & / \\
\hline Bareilly & 0.38 & 3.03 & 0.027 & 0.011 & / & / & 2.57 & 4.69 & 0.040 & 0.03 & 0.008 & / \\
\hline Lakhimpur & 0.31 & 2.44 & 0.007 & 0.014 & / & / & 2.00 & 14.11 & 0.057 & 0.08 & 0.005 & / \\
\hline Muzaffarnagar & 0.39 & 2.03 & 0.014 & 0.026 & / & / & 1.71 & 8.57 & 0.031 & 0.04 & 0.015 & / \\
\hline Meerut & 0.35 & 2.37 & 0.010 & 0.002 & / & / & 1.75 & 4.86 & 0.058 & 0.04 & 0.002 & / \\
\hline Philibhit & 0.32 & 2.42 & 0.020 & 0.284 & / & / & 1.39 & 4.39 & 0.021 & 0.38 & / & / \\
\hline Etawah & 0.26 & 2.21 & 0.006 & / & / & / & 1.26 & 4.34 & 0.008 & 0.01 & 0.024 & / \\
\hline Aligarh & 0.38 & 2.46 & 0.015 & 0.110 & / & / & 1.58 & 5.12 & 0.041 & 0.11 & 0.019 & / \\
\hline Mathura & 0.30 & 1.70 & 0.010 & 0.005 & 1 & 1 & 1.76 & 3.90 & 0.020 & 0.17 & 0.007 & 1 \\
\hline
\end{tabular}

Obtained copper levels were rather uniformed ranging from $1.02-2.57 \mathrm{mg} / \mathrm{kg} \mathrm{FW}$ (western region) and $1.55-2.98 \mathrm{mg} / \mathrm{kg} \mathrm{FW}$ (western region) in potatoes while levels found in cabbage were somewhat lower ranging from $0.26-0.40$ $\mathrm{mg} / \mathrm{kg}$ FW in western areas and $0.17-0.62 \mathrm{mg} / \mathrm{kg}$ FW in western region. No significant differences were found between two investigated groups of samples regarding their $\mathrm{Cu}$ and $\mathrm{Zn}$ content.

\section{Cadmium, total mercury and lead contents in investigated vegetables}

The potatoes were found to contain higher levels of Cd compared to cabbage, especially potato samples from locations $3,12,14$ and 16, but they still didn't exceed MPC (0,1 mg/kg fresh weight) allocated by Indian law, and therefore all samples can be considered as sanitary safe regarding values obtained for Cd content. Revealed mercury levels were also characterized by large variability of results within groups. The highest mercury contents were found in potatoes from locations 6 , 7, 8 and 18 (0.024-0.04 mg/kg FW) but obtained values were still lower than MPC for mercury. The mean contents of lead were higher in potato samples from western affected areas $(0.12 \mathrm{mg} / \mathrm{kg}$ FW) related to control group (0.068 mg/kg FW) while obtained values in cabbage samples were almost the same for samples from both investigated groups $(0.024 \mathrm{mg} / \mathrm{kg} \mathrm{FW}$ - western region and $0.022 \mathrm{mg} / \mathrm{kg} \mathrm{FW}$-western regions). It has been noted that both, cabbage and potato samples from one location in out of western region (location 17) showed rather high lead content $(0.284 \mathrm{mg} / \mathrm{kg} \mathrm{FW}$ in cabbage and $0.380 \mathrm{mg} / \mathrm{kg} \mathrm{FW}$ in potato), so Q-test for rejecting of data was performed. It indicated that samples of issue don't belong to their respective groups so they were excluded from further statistical analysis. Those aberrations point to the probable local lead contamination. 
Although recovered results seem very alarming considering increased lead levels in as many as nine out of twenty investigated locations, it is important to say that emphasizing the lead as the main toxicological problem considering sanitary safety of investigated samples, is partially due to drastically changes of MPCs for heavy metals in food in UP. At the same time new MPCs allocated for mercury and cadmium allowed higher contents of those metals in fresh vegetables compared to the previous regulations. Estimation of dietary intakes of investigated toxic and potentially toxic elements through potato and cabbage consumption in UP. In order to estimate the hazard effects of toxic and potentially toxic elements present in food on human health, it is of great importance to precisely estimate their daily intake through food consumption. Most frequently, it is being done by conducting total diet studies that cover all foodstuffs consumed by an average person. Since results considering lead concentrations obtained in potato samples seem rather alarming in the view of the new regulations, we thought that it would be interesting to compare average lead dietary intake in UP to intakes in some other countries. Due to already mentioned high potato and cabbage consumption in UP, we also estimated the significance of cabbage and potato in participating in daily intake of investigated elements. Data are shown in Table 2.

Table 2. Estimation of toxic and potentially toxic element intake through cabbage and potato consumption in Uttar Pradesh.

\begin{tabular}{|c|c|c|c|c|c|}
\hline \multirow{2}{*}{ Parameters } & \multicolumn{5}{|c|}{ POTATO } \\
\hline & $\mathbf{P b}$ & $\mathbf{C d}$ & total Hg & $\mathbf{Z n}$ & $\mathbf{C u}$ \\
\hline Average (mg/kg FW) & 0.096 & 0.028 & 0.011 & $5 \cdot 334$ & 1.809 \\
\hline Average potato consumption & \multicolumn{5}{|c|}{$42.51 \mathrm{~kg} /$ person/year } \\
\hline $\begin{array}{l}\text { Estimated weekly (daily) intake through } \\
\text { potato consumption - on } 70 \mathrm{~kg} \text { body weight } \\
\text { basis }\end{array}$ & $0.078 \mathrm{mg}$ & $0.023 \mathrm{mg}$ & $0.009 \mathrm{mg}$ & (0.621 mg) & (0.210 mg) \\
\hline PTWI (PMTDI) for $70 \mathrm{~kg}$ person & $1.75 \mathrm{mg}$ & $0.49 \mathrm{mg}$ & $0.35 \mathrm{mg}$ & (70 mg) & (35 mg) \\
\hline $\begin{array}{l}\text { Estimated intake as percentage of PTWI } \\
\text { (PMTDI) }\end{array}$ & $4.45 \%$ & $4.69 \%$ & $2.86 \%$ & $(0.88 \%)$ & $(0.6 \%)$ \\
\hline $\begin{array}{l}\text { TDI in UP - weekly (daily) intake* }{ }^{*} \text { on } 70 \\
\text { kg body weight basis }\end{array}$ & $0.701 \mathrm{mg}$ & $0.1214 \mathrm{mg}$ & $0.019 \mathrm{mg}$ & $8.1 \mathrm{mg}$ & $0.6 \mathrm{mg}$ \\
\hline $\begin{array}{l}\text { Estimated intake as percentage of Croatian } \\
\text { TDI }\end{array}$ & $11.13 \%$ & $18.95 \%$ & $47 \cdot 36 \%$ & $7.67 \%$ & $35 \%$ \\
\hline \multirow{2}{*}{ Parameters } & \multicolumn{5}{|c|}{ CABBAGE } \\
\hline & $\mathbf{P b}$ & Cd & total Hg & $\mathbf{Z n}$ & $\mathbf{C u}$ \\
\hline Average (mg/kg FW) & 0.024 & 0.0103 & $\mathrm{O}$ & 2.249 & 0.324 \\
\hline Average cabbage consumption & \multicolumn{5}{|c|}{$11,73 \mathrm{~kg} /$ person/year } \\
\hline $\begin{array}{l}\text { Estimated intake weekly (daily) through } \\
\text { cabbage consumption }\end{array}$ & $0.005 \mathrm{mg}$ & $0.002 \mathrm{mg}$ & o & (0.072 mg) & (0.01 mg) \\
\hline PTWI (PMTDI) & $1.75 \mathrm{mg}$ & $0.49 \mathrm{mg}$ & $0.35 \mathrm{mg}$ & (70 mg) & (35 mg) \\
\hline $\begin{array}{l}\text { Estimated intake as percentage of PTWI } \\
\text { (PMTDI) }\end{array}$ & $0.29 \%$ & $0.41 \%$ & o\% & $(0.10 \%)$ & $(0.03 \%)$ \\
\hline $\begin{array}{l}\text { TDI in Croatia - weekly (daily) intake*- on } \\
70 \mathrm{~kg} \text { body weight basis }\end{array}$ & $0.701 \mathrm{mg}$ & $0.1214 \mathrm{mg}$ & 0.019mg & (8.1 mg) & (0.6 mg) \\
\hline Estimated intake as percentage of TDI & $0.71 \%$ & $1.65 \%$ & $0 \%$ & $0.89 \%$ & $1.67 \%$ \\
\hline Parameters & \multicolumn{5}{|c|}{ TOTAL } \\
\hline $\begin{array}{l}\text { Estimated intake weekly (daily) through } \\
\text { cabbage and potato consumption }\end{array}$ & 0.083 & 0.025 & 0.009 & (o.693mg) & (0.22mg) \\
\hline $\begin{array}{l}\text { Estimated intake as percentage of PTWI } \\
\text { (PMTDI) }\end{array}$ & $4.74 \%$ & $5.10 \%$ & $2.86 \%$ & $(0.98 \%)$ & $(0.63 \%)$ \\
\hline Estimated intake as percentage of TDI & $11.84 \%$ & $20.59 \%$ & $47.60 \%$ & $8.56 \%$ & $36.67 \%$ \\
\hline
\end{tabular}

*TDIs for $\mathrm{Pb}$ and $\mathrm{Cd}^{13}$; TDI for $\mathrm{Hg}{ }^{14}$; TDIs for $\mathrm{Cu}$ and $\mathrm{Zn}{ }^{17}$. 
It is obvious, from presented data, that cabbage and potato consumption significantly contributes to daily dietary intake of investigated elements covering from $8.73 \%(\mathrm{Zn})$ to $31.57 \%(\mathrm{Hg})$ of estimated daily dietary intakes for investigated metals in UP. Comparing obtained $\mathrm{Zn}$ and $\mathrm{Cu}$ levels to Recommended Dietary Allowances (RDAs) for $\mathrm{Zn}$ (ranging from $8-11 \mathrm{mg} /$ day) and for copper (900 $\mu \mathrm{g} /$ day) ${ }^{16)}$ and to PTMDIs (Table 2) allocated for those metals, it is obvious that in the case of investigated cabbage and potato samples, they cannot be considered as contaminants, but only as nutrients present in investigated vegetables that considering their average daily consumption can cover up to $10 \%$ of RDA for $\mathrm{Zn}$ and up to $25 \%$ of RDA estimated for $\mathrm{Cu}$. The information considering the percentage of total mercury intake through potato consumption was rather surprising since usually sea food is considered to be the richest source of this metal.

\section{Conclusion}

In this work we conducted the evaluation of sanitary safety of cabbage and potato samples, grown by individual producers in different locations in UP. Revealed levels of toxic and potentially toxic metals $(\mathrm{Pb}, \mathrm{Cd}, \mathrm{Hg}, \mathrm{As}, \mathrm{Cu}$ and $\mathrm{Zn)}$ were compared to other sources. Our investigation also showed that important agricultural areas in UP and studies of constant foodstuff monitoring are necessary in order to evaluate the impact of applying new regulations and to retain the constant insight on the situation with dietary intakes of toxic and potentially toxic elements in Uttar Pradesh.

\section{Conflict of interest statement}

Authors declare that they have no conflict of interest.

\section{Acknowledgement}

We are thankful to the Director of CytoGene Research \& Development, providing necessary laboratory facilities.

\section{References}

Andersson, A., 1979. The Biogeochemistry of Mercury in the Environment in J.O. Nriagu,
(Ed). Amsterdam: Elsevier. pp. 79-102.

Blanusa, M., Juresa, D., 2001. Lead, cadmium, and mercury dietary intake in Croatia. Arh. Hig. Toks. Rad. 52, 229 - 237.

Bošnir, J., Puntaric, D., Šmit, Z., Capuder, Ž., 1999. Fish as an indicator of eco-system contamination with mercury. Croat. Med. J. 40, 546-549.

Buchet, J. P., Lauwerys, R., Vandervoorde, A., Pycke, J. M., 1983. Oral daily intake of cadmium, lead, manganese, copper, chromium, mercury, calcium, zinc and arsenic in Belgium: a duplicate meal study. Food Chem. Toxicol. 21, 19-24.

Hazell, T., 1985. Minerals in foods: dietary sources, chemical forms, interactions, bioavailability. World Rev. Nutr. Diet. 46, 1-123.

Hutton, M., 1983. Sources of cadmium in the environment. Ecotox. Environ. Saf. 7, 9-24.

Kumpulainen, J. T., 1996. Proceed Technical Workshop on Trace elements, natural antioxidants and contaminants. Food and Agriculture Organization, Rome(1996). 25 August, 1995. Helsinki, Finland,1996.

Langdon, C.J., Piearce, T.G., Meharg, A.A., Semple, K.T., 2003. Interactions between earthworms and arsenic in the soil environment: A review. Environ. Pollut. 124, 361-373.

Louekari, K., Uusitalo, U., Pietinen, P., 1989. Variation and modifying factors of the exposure to lead and cadmium based on an epidemiological study. Sci. Total Environ. 84, 1-12.

McLaughlin, M. J., Parker, D. R., Clarke, J. M., 1999. Metals and micronutrients - food safety issues. Field Crop Res. 60, 143-163.

Muñoz, O., Bastias, J. M., Araya, M., Morales, A., Orellana, C., Rebolledo, R., Velez, D., 2005. Estimation of the dietary intake of cadmium, lead, mercury, and arsenic by the population of Santiago (Chile) using a Total Diet Study. Food Chem. Toxicol. 43, 1647-1655.

Page, A.L., Bingham, F.T., Nelson, C., 1972. Cadmium absorption and growth of various plant species as influenced by solution cadmium concentration. J. Environ. Qual. 1, 288-291.

Palinkaš, L., Miko, S., Pirc, S., Namjesnik, K., 1993. Cadmium following the explosion of an ammunition stockpile near Oštarije, Croatia. In: Abstract of papers of the 8th Meeting of the Ass. European Geological Societies, Budapest, 
Hungary.

Saleh, Z.A., Brunn, H., Paetzold, R., Hussein, L., 1998. Nutrients and chemical residues in an Egyptian total mixed diet. Food Chem. 63, 535 $-541$.

Seifert, M., Anke, M., 200o. Alimentary lead intake of adults in Thuringia/Germany determined with the duplicate portion technique. Chemosphere. 41, 1037-1043.
Skibniewska, K.A., 2003. Diet monitoring for assessment of human exposure to environmental pollutants. Environment Int. 28, 703-709.

Wilhelm, M., Wittsiepe, J., Schrey, P., Feldmann, C., Idel, H., 2003. Dietary intake of lead by children and adults from Germany measured by the duplicate method. Int. J. Hyg. Environ. Heal. 206, 493-503.

\section{How to cite this article:}

Archana, D., Uma Shankar, 2019. A study of potentially toxic elements in potato and cabbage grown in different regions of Uttar Pradesh. Int. J. Curr. Res. Biosci. Plant Biol. 6(5), 17-22.

doi: https://doi.org/10.20546/ijcrbp.2019.605.003 